\title{
Analysis of Factors Affecting Preeclampsia in Dr. Moch. Ansari Saleh Hospital
}

\author{
Sri Purwanti *, Husaini ${ }^{*}$, Lenie Marlinae ${ }^{* *}$, Roselina Panghiyangani ${ }^{* * *}$, Triawanti $^{* * * *}$ \\ * Master of Public Health, Faculty of Medicine, Lambung Mangkurat University, Indonesia \\ ** Public Health Study Program, Faculty of Medicine, Lambung Mangkurat University, Indonesia \\ *** Department of Biomedicine, Faculty of Medicine, Lambung Mangkurat University, Indonesia \\ ***** Department of Biochemistry, Faculty of Medicine, Lambung Mangkurat University, Indonesia \\ DOI: 10.29322/IJSRP.10.06.2020.p10272 \\ http://dx.doi.org/10.29322/IJSRP.10.06.2020.p10272
}

\begin{abstract}
Preeclampsia is a complication in pregnancy that can cause serious illness, disability, and can cause death on maternal, fetal and neonates. In 2018, preeclampsia was the second of the tenth diseases in the maternity room of Dr. Moch Ansari Saleh Hospital Banjarmasin. One of the maternal deaths in South Kalimantan Province is caused by preeclampsia. The most cause of maternal deaths in South Kalimantan is hypertension, namely as many as 26 people $(32.91 \%)$ while in 2017 , maternal deaths caused by hypertension were 19 people $(25.33 \%)$. This research aims to analyze actors that influence the incidence of preeclampsia in Dr Moch Ansari Saleh Hospital Banjarmasin. The study begins by determining a case (mothers who have preeclampsia) and control (mothers who did not have preeclampsia). The number of samples in the study was 72 samples with accidental sampling technique. The results showed that there was an influence between parity $(\mathrm{p}=0.009)$ and history of hypertension $(\mathrm{p}=0.003)$ of maternity mothers on the incidence of preeclampsia. There was no effect between age $(p=0.562)$ and maternal work status on the incidence of preeclampsia. The results of multiple logistic regression analysis showed a history of hypertension $(p=0.003)$ and Exp. B (5.616) as the most dominant factors influencing the incidence of preeclampsia. There is an influence between parity and hypertension history on the incidence of preeclampsia. There is no influence between age and employment status on the incidence of preeclampsia. The most dominant factor influencing the incidence of preeclampsia is a history of hypertension.
\end{abstract}

Index Terms- age, parity, history of hypertension, employment status

\section{INTRODUCTION}

$\mathrm{P}$ Preeclampsia is a disease characterized by an increase in blood pressure of more than $140 / 90 \mathrm{mmHg}$, proteinuria and oedema that occur in pregnancy after the 20th week or up to 48 hours postpartum (1). Preeclampsia is a disease with clinical symptoms of hypertension and proteinuria arising caused because of pregnancy due to the occurrence of vasospasm and endothelial activation in the current worth pregnancies over 20 weeks. Preeclampsia is one of the complications in pregnancy that can cause serious illness, disability, and can cause death in the mother, fetus and neonate (2). Risk factors for preeclampsia and eclampsia include primigravida, age, history of preeclampsia or eclampsia, kidney disease and hypertension that existed before pregnancy, multiple pregnancy, and obesity. However, from some of these risk factors, it is still challenging to determine which factors are the most dominant (3).

The cause of maternal mortality in Indonesia is still dominated by bleeding $(30.3 \%)$, hypertension in the pregnancy $(27.1 \%)$, and infection (7.3\%) (4). Preeclampsia and eclampsia are among the causes of maternal death. According to the World Health Organization (WHO) in 2015, states that the cause of maternal death is the most common bleeding (28\%), preeclampsia/eclampsia (24\%), infection (11\%), while the indirect cause is trauma obstetric (5\%) and others (11\%) (5). Preeclampsia is one of the most frequent medical complications in pregnancy, with an incidence rate of around 3-14\%. Around the world, there are reported 50,000 to 70,000 deaths each year due to preeclampsia. This disorder is the cause of about $16 \%$ of maternal deaths in developed countries. In the United States reported rates of preeclampsia are around 5\% to $8 \%$ of all pregnancies (6). In 2018 , the highest cause of maternal mortality in South Kalimantan was hypertension, 26 people (32.91\%), while in 2017 maternal deaths caused by hypertension were 19 people $(25.33 \%)$, this showed that an increase in the percentage maternal mortality caused by hypertension that is equal to $7.58 \%$.

Pre-eclampsia and eclampsia are exclusively a disease of null fig. It is usually found in infertile women of high-risk age, in teenagers or women older than 35 years (7). History of hypertension is also one of several risk factors that influence the incidence of preeclampsia. A mother who has a history of hypertension is a mother who has blood pressure or heart rate that is higher than normal due to narrowing of the arteries or other disorders that a person has experienced. A woman who has a history of hypertension has a 9.817 times greater chance of developing preeclampsia compared to respondents who have no history of hypertension. Likewise, with maternal employment status, pregnant women who do jobs that require prolonged standing an increase of $20-60 \%$ risk of hypertension in jobs demanding physical activity (8). Based on the background above, making the reason for the authors to examine the risk factors that influence the incidence of preeclampsia in maternity in Dr Moch Ansari Saleh Hospital. 


\section{RESEARCH METHOD}

The study begins by determining a case (mothers who have preeclampsia) and control (mothers who did not develop preeclampsia). They traced retrospectively to look back if there is a risk factor that is seen from age who are at risk or no-risk on the incidence of preeclampsia at Dr. Moch. Ansari Saleh Hospital. This study uses a survey method and uses a checklist sheet as a tool for data collection. The population in this study were all women giving birth at Dr. Moch. Ansari Saleh Banjarmasin. The sampling technique in this study is accidental sampling.

\section{FINDINGS}

Table 1. Univariate Analysis of Research Variables Variable Category is higher than normal due to narrowing of the arteries or other disorders that a person has experienced. A woman who has a history of hypertension has a 9.817 times greater chance of developing preeclampsia compared to respondents who have no history of hypertension. At least have the opportunity to experience preeclampsia by 3,683 times, and most likely have the opportunity to experience preeclampsia he weight of 26.168 times (10).

Based on the above table 1, it is known that both in the case and control group, the majority of respondents were mothers who did not work. There were $88.9 \%$ of respondents in case group and $91.7 \%$ of respondents in the control group that did not work. Pregnant women who do work that requires long-standing risks a $20-60 \%$ increase in hypertension in work that requires a lot of Freguesngativity (11).

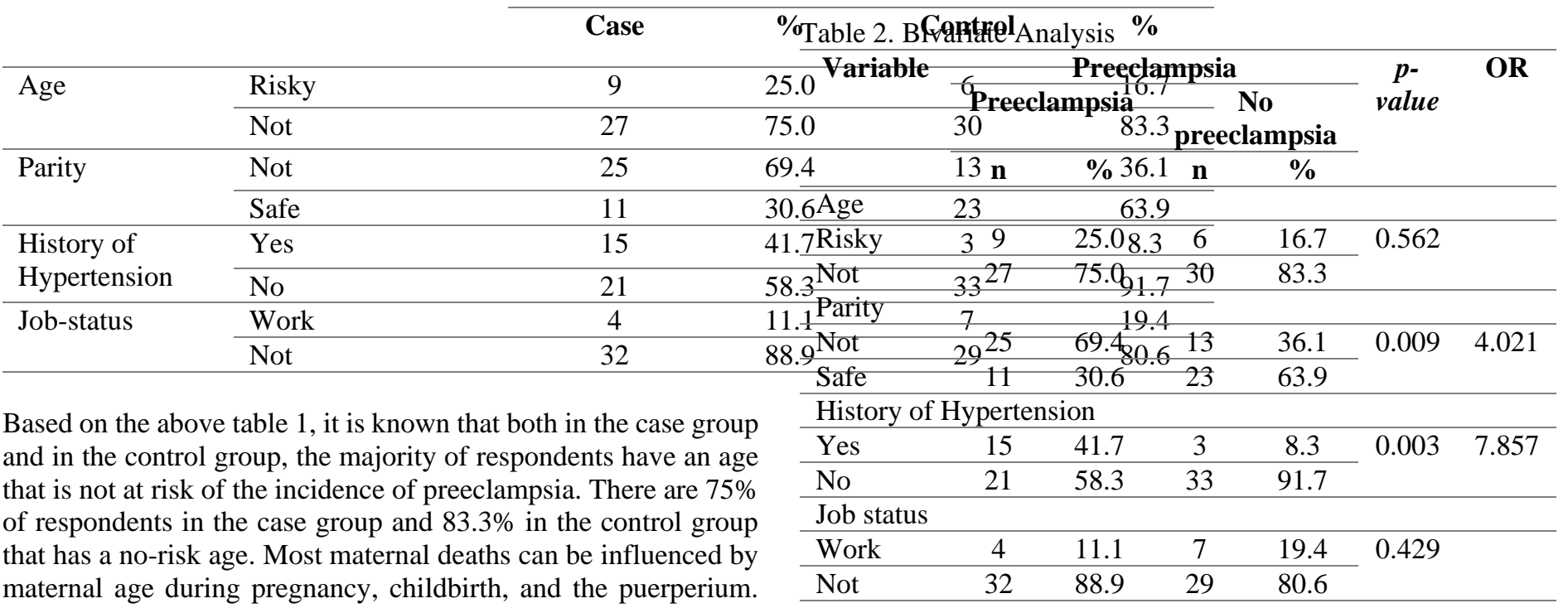

Age meant here is the mother that had aged under 20 years and more than 35 years, but there are still many women who do not know that age becomes one of the high-risk factors for the future to become pregnant early, childbirth, and postpartum. Meanwhile, the right age for pregnancy, childbirth, and childbirth is at reproductive age between 20-35 years. This age range is the safest period for pregnancy and childbirth because, at that age, the risk of pregnancy complications is lower (9).

Based on the table 1 above, it is known that in the case and control group, the majority of respondents had safe parity. There were $69.4 \%$ of respondents in the case group with safe parity and $63.9 \%$ of respondents in the control group with safe parity. Parity of 2-3 is the parity that is most secure when viewed from the angle of maternal deaths. Parity highest (more than 3 ) has maternal mortality rates are higher. In primigravida, eclampsia usually occurs because mothers who are first pregnant often experience stress in the face of childbirth. Whereas in multigravida, the risk of pregnancy increases for mothers to be affected by eclampsia due to higher parity, higher maternal deaths.

Based on the above table 1, it is known that both in the case group and in the control group, the majority of respondents did not have a history of hypertension. There were $58.3 \%$ of respondents in the case group and $91.7 \%$ of respondents in the control group who had no history of hypertension. A mother who has a history of hypertension is a mother who has blood pressure or heart rate that

Based on table 2 above, it can be seen that there are variables that influence the incidence of preeclampsia in the Dr Moch Ansari Saleh Hospital, namely parity ( $\mathrm{p}$-value $=0.009$ ) with an OR value of 4.021 and history of hypertension ( $\mathrm{p}$-value $=0.003$ ) with an OR value of 7.857. In contrast, variables that did not affect preeclampsia were age $(\mathrm{p}$-value $=0.562)$ and status occupation $(\mathrm{p}$ value $=0.429$ ).

Table 3. Multivariate Analysis

\section{Independent Variable}

\begin{tabular}{lll}
\hline Parity & 0.061 & 2.885 \\
History of Hypertension & 0.019 & 5.616 \\
\hline
\end{tabular}

Based on the table above, it can be seen that the most dominant variable has an influence on the incidence of preeclampsia at the Dr Moch Ansari Saleh Hospital, namely a history of hypertension (p-value $=0.019)$ with an $\operatorname{Exp}(B)$ of 5.616. maternal maternity with a history of hypertension will have the opportunity of 5.616 times more likely to have preeclampsia than maternity mother with no history of hypertension. 


\section{DISCUSSION}

Preeclampsia is a disease with clinical symptoms such as hypertension and proteinuria that arise due to pregnancy due to the occurrence of vasospasm and endothelial activation when the gestational age is above 20 weeks. Preeclampsia and eclampsia are among the causes of maternal death. Preeclampsia is one of the complications in pregnancy that can cause severe illness, disability, and can cause death in the mother, fetus and neonates. Therefore, the incidence of preeclampsia can be prevented by looking at the factors that can influence the incidence of preeclampsia. The incidence of preeclampsia can be influenced by parity and history of hypertension. Risk factors for preeclampsia and eclampsia include primigravida, age, history of preeclampsia or eclampsia, kidney disease and hypertension that existed before pregnancy, multiple pregnancy, and obesity.

Some risk factors for hypertension in pregnancy/preeclampsia/eclampsia include age, parity, race/ethnic, heredity, genes, diet/nutrition, climate/season, and social/economic behaviour (12). Judging from the characteristics that exist in maternity there are several risk factors that can affect the incidence of preeclampsia at the Dr. Moch Ansari Saleh Hospital namely parity $(\rho$-value $=0.009)$ and history of hypertension $(\rho$-value $=0.001)$. This is in line with research by Veftisia (2018) which shows that primiparous mothers have a risk of experiencing preeclampsia during pregnancy by 0.83 times. This is consistent with the theory that in the first pregnancy there will be the formation of "Human Leucocyte Antigen Protein G (HLA)" which plays an important role in modulating the immune response so that the mother rejects the results of conception (placenta) or there is maternal intolerance of the placenta resulting in preeclampsia. Parity 2 to 3 is the safest parity from the point of view of maternal death.

The most dominant risk factors that influence the incidence of preeclampsia in maternal mothers are mothers who have a history of hypertension ( $\mathrm{p}$-value $=0.019$ ) with an $\operatorname{Exp}(\mathrm{B})$ value of 5.616. It means that mothers maternity with a history of hypertension will have the opportunity of 5.616 times more likely to have preeclampsia than right with mom maternity with no history of hypertension. This is in line with research conducted by Hasliani (2018) which states that there is a significant relationship between the history of hypertension and the incidence of preeclampsia in pregnant women in Pangkep District Hospital (13). Likewise, Mariza's research (2016) which states that respondents with a history of hypertension have a greater chance of experiencing severe preeclampsia 9.817 times compared to respondents who do not have a history of hypertension. At least have a chance of experiencing severe preeclampsia by 3,683 times, and the greatest has a chance of experiencing severe preeclampsia by 26.168 times (14).

\section{CONCLUSION}

Based on the results of research and discussion, it can be concluded as follows:

1. There is no influence of age and occupational status factors on the incidence of preeclampsia in the Dr Moch Ansari Saleh
Hospital.

2. There is an influence of parity factor and history of hypertension on the incidence of preeclampsia at Dr Moch Ansari Saleh Hospital.

3. The history of hypertension variables is the most influential on the incidence of preeclampsia in the Dr Moch Ansari Saleh Hospital.

\section{REFERENCES}

1. Wahyuni, R., Azhari., Nursari Abdul Syukur. (2019) Relationship between Obesity and Preeclampsia in Pregnant Women Trimester Ii and III. Mahakam Midwifery Journal . 2 (5); 312-323.

2. Novianti, H. (2016) Effect of Age and Parity Against the Incidence of PreEclampsia in Sidoarjo Rsud. Scientific Journal of Health. 9 (1); 25-31.

3. Sumampouw, CM., Hermie M. M. Tendean., Freddy W. Wagey, (2019) Picture of Severe Preeclampsia and Eclampsia in Terms of Risk Factors in Prof. Dr. RD Kandou Manado. Journal of Medical and Rehabilitation. 1 (3); $1-5$.

4. Ministry of Health, (2017) Indonesian Health Profile. Ministry of Health of the Republic of Indonesia. Jakarta.

5. Yuniarti, F., Wahyu Wijayati., Dintya Ivantarina. (2018) Analysis of Health Behaviors and Risk Factors for the Occurrence of Preeclampsia in Pregnant Women in the Gynecology Obstetrics Clinic of Kediri District Hospital. Journal of Issues in Midwifery. 1 (3); 1-17.

6. Yanti, I., Nelly Apriningrum., Lilis Suryani. (2017) Multivariate Analysis of Relationships Between Age, Parity, Disease History, Calcium Consumption With The Incidence Of Preeclampsia In Pregnant Women. Unsika Journal . 2 (1); 63-73.

7. Hipson, M. (2016) Relationship between Age, Parity and Mother's Education and the Incidence of Eclampsia in Muhammadiyah Hospital Palembang. Proceedings. Muhammadiyah University of Semarang. Semarang.

8. Gustri, Y., Rico Januar Sitorus., Feranita Utama. (2016) Determinants of Preeclampsia in Pregnant Women at RSUP dr. Mohammad Hoesin Palembang. Journal of Public Health Sciences . 7 (3); 209-217.

9. Fatkhiyah, N., Kodiyah., Masturoh. (2016) Maternal Determinants of Preeclampsia. The Soedirman Journal of Nursing (The Soedirman Journal of Nursing). 11 (1); 53-61.

10. Mariza, A., Rosmaida Siregar. (2016) Relationship between History of Hypertension and the Occurrence of Severe Preeclampsia in Women in RSUD dr. H. Abdul Moeloek Lampung Province in 2015. Journal of Midwifery. 2 (4); 183-187.

11. Imaroh, I., Sri Achadi Nugraheni., Dharminto. (2018) Risk Factors Affecting the Occurrence of Hypertension in Pregnant Women in the Work Area of the Kedungmundu Health Center, Semarang City in 2017. Journal of Public Health (E-Journal ). 6 (1); 570-580.

12. Sulfianti., Handayani., Siti Juhariyah. (2016) Neonatal Obstetric Emergency First Aid. PPGDON Module. Jakarta.

13. Hasliani, A (2018) Relationship of History of Hypertension with the Incidence of Preeclampsia in Rsud Pangkep . Scientific Journal of Health Diagnosis. 12 (1); 162-166

14. Veftisia, V., Yulia Nur Khayati. (2018) Relationship between Parity and Mother's Education and the Incidence of Preeclampsia in Semarang Regency. Journal of Research Midwifery Tegal Polytechnic. 7 (2); 336-339.

\section{AUTHORS}

First Author - Sri Purwanti, Master of Public Health, Faculty of Medicine, Lambung Mangkurat University, Indonesia.

Second Author - Husaini, Master of Public Health, Faculty of Medicine, Lambung Mangkurat University, Indonesia.

Third Author - Lenie Marlinae, Public Health Study Program, Faculty of Medicine, Lambung Mangkurat University, Indonesia. Fourth Author - Roselina Panghiyangani, Department of Biomedicine, Faculty of Medicine, Lambung Mangkurat University, Indonesia. 
Fifth Author - Triawanti, Department of Biochemistry, Faculty of Medicine, Lambung Mangkurat University, Indonesia.
Correspondence Author - Sri Purwanti, Master of Public Health, Faculty of Medicine, Lambung Mangkurat University, Indonesia, email: wanty2727@gmail.com 